\title{
The Location of VIP in the Pancreas of Man and Rat
}

\author{
A. E. Bishop, J. M. Polak, I. C. Green ${ }^{2}$, M. G. Bryant ${ }^{1}$, and S. R. Bloom ${ }^{1}$ \\ Departments of Histochemistry and ${ }^{1}$ Medicine, Royal Postgraduate Medical School, Hammersmith Hospital, London \\ and ${ }^{2}$ Department of Biochemistry, University of Sussex, Falmer, Brighton, Sussex, England
}

Summary. VIP has powerful stimulatory effects on both endocrine and exocrine pancreas but its localisation within the gland has not been established. In this study, human pancreas was obtained fresh at surgery (eleven) or within four hours of death (seven). The pancreas was also removed from rats (twenty-two). Immunocytochemical staining showed VIP to be present in fine nerve fibres in all areas of the pancreas. Many fibres were seen in the exocrine pancreas, running between the acini, and around ducts and blood vessels. In addition, dense networks of fibres were observed forming meshes around islets and occasional ganglia were found containing immunoreactive cell bodies. In general, there were fewer VIP fibres in the rat pancreas than in the human, but overall distribution was identical. The mean VIP content of whole human pancreatic tissue was $42 \pm 10 \mathrm{pmol} / \mathrm{g}$ wet weight $(38 \pm 9 \mathrm{pmol} / \mathrm{g}$ in head, $49 \pm 6 \mathrm{pmol} / \mathrm{g}$ in body and $42 \pm 11 \mathrm{pmol} / \mathrm{g}$ in tail). Whole rat pancreatic tissue contained $28 \pm$ $7 \mathrm{pmol} / \mathrm{g}$ wet weight while preparations of isolated islets were found to contain $374 \pm 30 \mathrm{pmol} / \mathrm{g}$. It is possible that the heavy VIP innervation of the islets described here indicates a role in the regulation of islet hormone release.

Key words: Immunocytochemistry, radioimmunoassay, pancreas, gut hormones, vasoactive intestinal polypeptide.

Vasoactive intestinal polypeptide (VIP) is a basic, twenty-eight amino acid peptide, first isolated and purified by Said and Mutt in 1972 [1]. It has a widespread distribution throughout the body where it appears to be predominantly localised in nervous tissue $[2,3,4]$. In peripheral tissue VIP is found mostly in fine varicose nerve fibres, for example in the gas- trointestinal tract [5], salivary glands [6] and genital tract $[7,8,9,10]$.

VIP has a range of biological activities including systemic vasodilation and the stimulation of gut motility and secretion [11]. It also influences both the endocrine and exocrine pancreas stimulating the release of somatostatin [12], glucagon [13, 14, 15] insulin $[13,14,15]$ and pancreatic polypeptide [14] and the secretion of alkaline bicarbonate juice [14, $16]$.

In view of these potent effects, and the recent expansion $[17,18]$ of the earlier brief reports of the presence of VIP nerves in the human pancreas $[2,3]$ further, more detailed investigation seemed warranted.

A combined immunocytochemical and radioimmunoassay study was used to establish both the exact quantities of VIP present and the precise localisation of the peptide within the various pancreatic structures in man. In addition, the rat pancreas was examined because of the possibility of obtaining isolated islets for extraction.

\section{Materials and Methods}

\section{Source of Tissue}

Human. Eighteen fresh surgical specimens of pancreas were obtained during the removal of carcinomas of the exocrine pancreas (two) and APUDomas [19] (six insulinomas and one as yet unidentified). One normal pancreas was obtained during a therapeutic splenectomy and one "normal" specimen was taken from a patient suspected of having an endocrine tumour but in whom, on conventional histological examination, no tumour was found.

In addition, five whole non-diseased specimens were taken within four hours of death at post-mortem examination.

Rat. A total of twenty-two male and female Sprague-Dawley rats, weighing between $200-300 \mathrm{~g}$ was used. Whole pancreas was removed from twelve rats. In addition, islets were obtained from a further ten Sprague-Dawley rats (weight 200-250 g) [20]. The 
pancreas was taken and distended with bicarbonate buffered medium [21], chopped and treated with collagenase for 10-15 min to free the islets. The islets were then removed, using a fine pipette, and frozen in a small amount of buffered medium in batches of 200 for extraction.

\section{Immunocytochemistry}

The tissues were all fixed in $\mathrm{p}$-benzoquinone, either in solution or in vapour form [22]. Care was taken to ensure that the pancreata studied were completely normal, on conventional histological examination.

Samples of pancreas, measuring no more than $0.5 \times 0.5 \times$ $0.5 \mathrm{~cm}$, were fixed by immersion in $0.4 \%$ benzoquinone in phosphate buffered saline (PBS) $10 \mathrm{nmol} / \mathrm{l}, \mathrm{pH} 7.1-7.4$ ) for $2 \mathrm{~h}$ at $4^{\circ} \mathrm{C}$ [23]. Fixation was followed by thorough rinsing in sucrose in PBS $(0.2 \mathrm{~mol} / \mathrm{l})$. The fixed tissue was then mounted on cork mats and snap frozen in Arcton (Freon) pre-cooled $\left(-145^{\circ} \mathrm{C}\right)$ in liquid nitrogen. Sections of $15 \mu$ were cut in a cryostat at $-20^{\circ} \mathrm{C}$, mounted on slides previously coated with a solution of gelatin and formalin $(1: 1 \mathrm{v} / \mathrm{v}, 1 \%$ gelatin: $2 \%$ formalin) and air-dried for at least $30 \mathrm{~min}$. For fixation in benzoquinone vapour, samples of pancreas, no larger than $1 \times 1 \times 0.3 \mathrm{~cm}$. were rapidly frozen in melting Arcton and freeze-dried overnight at $-40^{\circ} \mathrm{C}$. The tissue was exposed to benzoquinone vapour for three hours at $60^{\circ} \mathrm{C}$ and infiltrated with paraffin wax for $90 \mathrm{~min}$ [22]. Sections of $10 \mu$ were cut and mounted on uncoated slides.

Immunocytochemistry was carried out by the use of indirect immunofluorescence and by the unlabelled antibody enzyme (peroxidase-anti-peroxidase or PAP) method [24]. For the indirect immunofluorescence technique, sections were incubated with VIP antiserum (dilution 1:300) for $16-20 \mathrm{~h}$ in a moist atmosphere at $4^{\circ} \mathrm{C}$. A second layer of fluorescein conjugated goat anti-rabbit globulin was applied at a dilution of $1: 150$ for one hour at room temperature. Sections were mounted in PBS-glycerine (1:9 v/v PBS: glycerine) and examined under a Leitz ultra-violet microscope.

The PAP technique involved the pre-treatment of sections by immersion in $0.03 \%(\mathrm{v} / \mathrm{v})$ hydrogen peroxide in PBS for 30 min to remove endogenous peroxidase activity. Possible background staining was also removed by the application of normal goat serum, dilution $1: 30$, for $30 \mathrm{~min}$ at room temperature. The VIP antiserum was used at a dilution of 1:1200 and incubation was for $16-20 \mathrm{~h}$ at $4^{\circ} \mathrm{C}$. The second layer of unconjugated goat anti-rabbit globulin (Miles Laboratories) was used at a dilution of 1:50 for $30 \mathrm{~min}$. The final layer consisted of PAP complex (UCB Laboratories), dilution $1: 300$, and incubation was again for $30 \mathrm{~min}$ at room temperature. Visualisation of the PAP complex was achieved by the diaminobenzidine method of Graham and Karnovsky [25]. When developed the sections were dehydrated, mounted in DPX and examined under a Leitz transmitted light microscope.

Controls were those proposed by Stemberger [24] including the use of VIP antiserum which had previously been incubated with excess VIP $(0.1 \mathrm{nmol} / \mathrm{ml}$ of diluted antiserum). Non-immune rabbit serum was used as first layer and either the fluorescein conjugated globulin or the PAP complex was used alone.

A semi-quantitative assessment of VIP fibre populations in human and rat pancreas was carried out using an arbitrary counting method. This involved the counting of the points of intersection of VIP fibres and the lines on an eye-piece graticule which consisted of a grid of 100 equal sized squares. Five different fields were examined on two sections from four randomly chosen human and rat specimens. The sections were immunostained using the peroxidase-anti-peroxidase technique and examined under the $x$ 25 objective of a Leitz transmitted light microscope. The results were analysed by the application of an unpaired Student's t-test.

\section{Radioimmunoassay}

For the whole pancreas material the tissues were kept deep frozen until the time of extraction. They were then weighed while still deep frozen and plunged into vigourously boiling water for $5 \mathrm{~min}$, cooled, homogenised in $5 \mathrm{ml}$ of water/g of tissue and then centrifuged at $2500 \mathrm{~g}$ for $10 \mathrm{~min}$. The tissue pellet was then reextracted in a similar manner using $4 \mathrm{ml}$ of water/g wet weight and the two supernatants were pooled. The gross tissue pellets were then re-extracted a further two times with $5 \mathrm{ml}$ and $4 \mathrm{ml} / \mathrm{g}$ of $0.1 \mathrm{~mol} / \mathrm{l}$ formic acid. After final centrifugation, acid extracts were pooled and water and acid extracts were assayed separately [26].

Each batch of isolated islets was weighed whilst still deep frozen and then boiled for $2 \mathrm{~min}$ in $0.5 \mathrm{ml}$ of water. After cooling the islets were homogenised in $0.5 \mathrm{ml}$ of water and centrifuged for $10 \mathrm{~min}$ at $2500 \mathrm{~g}$. The resulting supernatant was removed and saved and the tissue debris was re-extracted with a further $0.5 \mathrm{ml}$ of water. Both water extracts were pooled for assay. The tissue debris was then re-extracted a further two times in $0.1 \mathrm{mmol} /$ $10.1 \mathrm{~mol} / 1$ formic acid under identical conditions as for the water extraction, and the extracts were pooled and assayed. The VIP antiserum was used at a final dilution of $1: 320,000$ to give $50 \%$ binding of $1 \mathrm{fmol}{ }^{125} \mathrm{I}$-VIP in $800 \mathrm{ml}$ after 3 days incubation at $4^{\circ} \mathrm{C}$. Under these conditions the assay was sensitive to changes of $3 \mathrm{fmol} /$ assay tube ( $95 \%$ confidence limit) using pure porcine VIP as standard.

Radioactive VIP label was prepared by a modification of the lacto-peroxidase method. A trace iodination technique was employed followed by high resolution ion exchange chromatography for purification of the monoiodinated VIP. The resulting ${ }^{125} \mathrm{I}$ VIP label had a specific activity of between 1.6 and $1.0 \mathrm{mCi} / \mathrm{mol}$ and remained stable for up to three months at $-20^{\circ} \mathrm{C}$ [26].

Statistical examination of the results was carried out by analysis of variance and by the application of the unpaired Student's t-test.

\section{VIP Antisera}

The VIP antisera for immuncytochemistry and radioimmunoassay were raised in New Zealand white rabbits against natural porcine VIP coupled to bovine serum albumin by the carbodiimide method [26].

The antisera reacted with C-terminal synthetic VIP fragments (but not $\mathrm{N}$-terminal fragments) and showed no cross-reactivity with secretin, glucagon or gastric inhibitory peptide, which are structurally related to VIP, or with any of the known neuropeptides: bombesin [27], gastrin [28], cholecystokinin [29], neuroten$\sin [30]$, somatostatin [31], substance P [32] and enkephalin [33].

\section{Chromatography}

For gel chromatography $2 \mathrm{ml}$ of human pancreas extract was loaded on to a $1.5 \times 90 \mathrm{~cm}$ Sephadex G50 superfine column precalibrated with dextran blue (Vo), cytochrome C, natural porcine VIP and $\mathrm{Na}^{125} \mathrm{I}(\mathrm{Vt})$ as molecular size markers. The column was eluted with $0.1 \mathrm{mmol} / 1$ formic acid and, with the exception of porcine VIP, the above markers were included in each column load sample of pancreas extracts.

\section{Results}

\section{Immunocytochemistry}

In the human pancreas, immunocytochemistry, by both indirect immunofluorescence and the unlabelled antibody enzyme method, localised VIP to fine, vari- 
cose nerve fibres which showed a widespread distribution throughout the organ. Fibres were seen in the exocrine pancreas, between acini (Fig. 1) and around ducts and blood vessels. The endocrine cells were found to have a particularly rich supply of VIP fibres which enmeshed the islets forming peri-insular networks (Fig. 2). This neuro-insular complex was a consistent finding in all the specimens. VIP fibres could also be seen to be in contact with, and sometimes appeared to terminate on, the pancreatic endocrine cells.

Occasional large nerves, containing parallel aligned VIP fibres, were observed and these were often in proximity to ganglia containing immunoreactive and non-immunoreactive cell bodies (Fig. 3). No appreciable differences were noted in the number and distribution of VIP fibres when comparative studies were carried out between (a) the three anatomical areas (head, body and tail) and (b) a normal non-tumourous pancreas and pancreas surrounding either carcinomas or any of the types of endocrine tumour. These subjective immunocytochemical findings were fully corroborated by the radioimmunoassay determination of the VIP content of the various specimens (Table 1).

A similar overall distribution of VIP fibres was seen in the rat pancreas although there appeared to be fewer fibres than in the human tissue. A semiquantitative assessment of the immunocytochemical findings showed that the number of VIP fibres in the human pancreas was almost twice that in the rat pancreas. This difference was statistically significant $(\mathrm{p}<0.001)$.

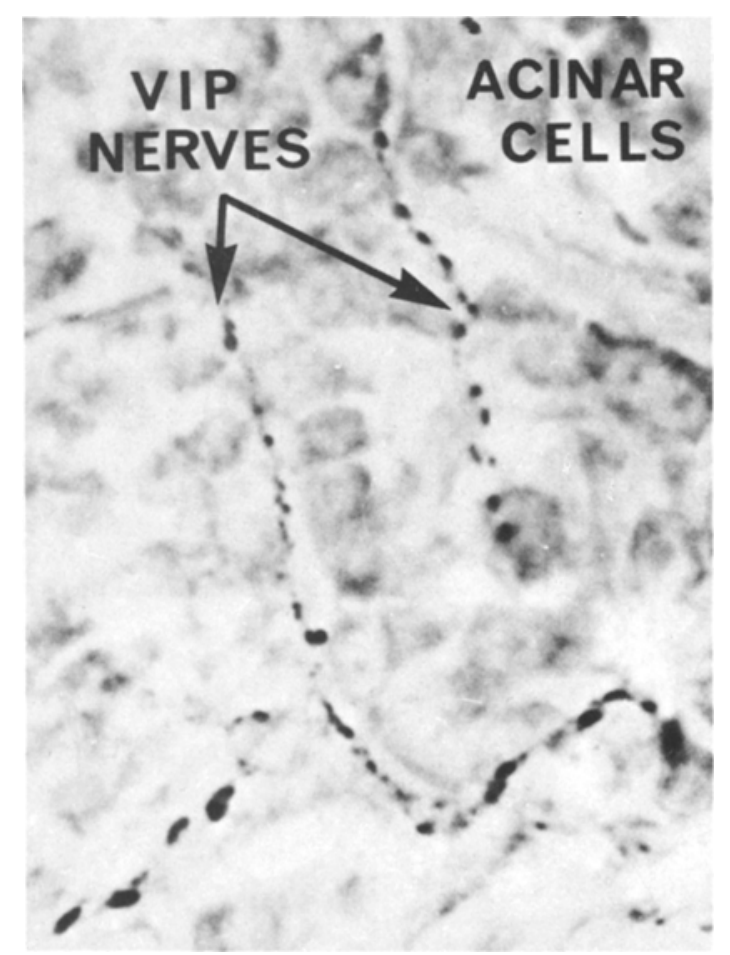

Fig. 1. VIP containing fibres, immunostained by the unlabelled antibody enzyme method (PAP), running through acinar tissue of the human pancreas. Tissue was fixed in $\mathrm{p}$-benzoquinone and the $15 \mu$ sections were not counterstained $(\times 650)$
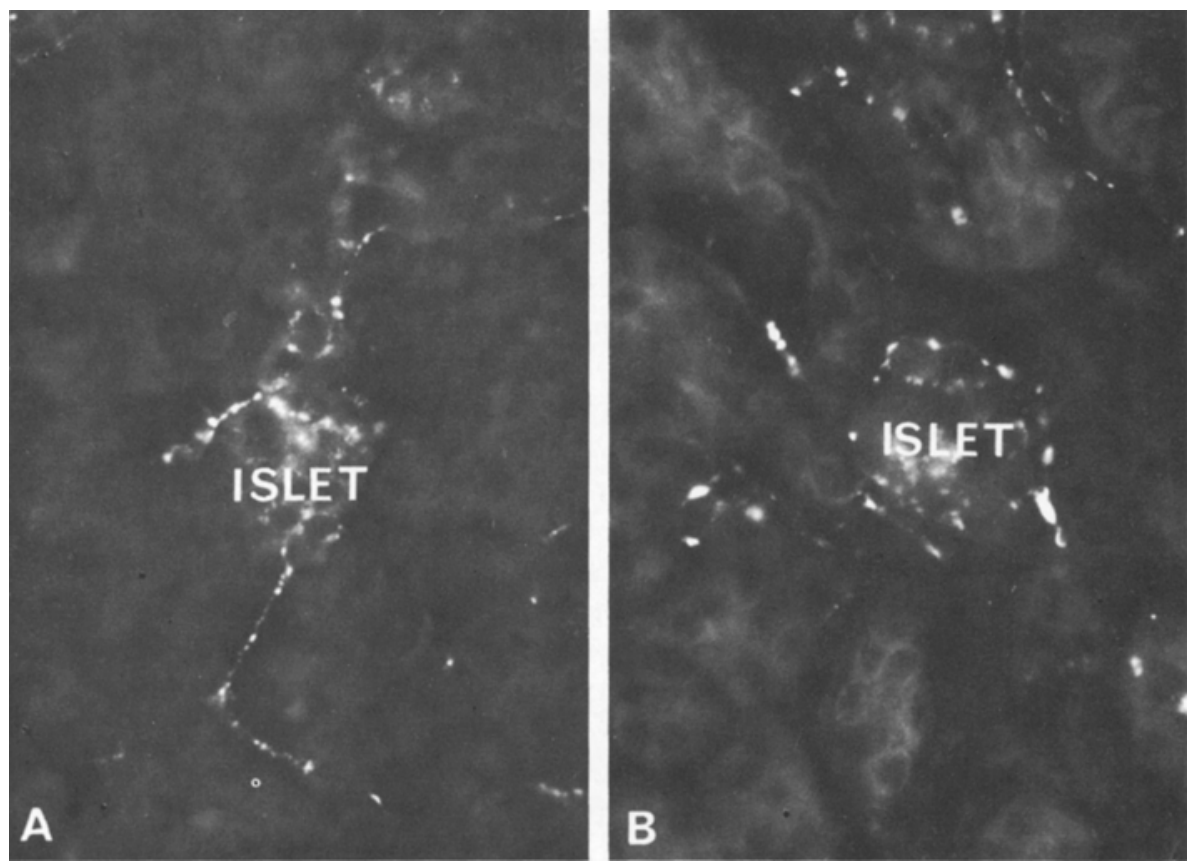

Fig. $2 \mathrm{~A}$ and B. VIP fibres, immunostained by the indirect immunofluorescence technique, in $15 \mu$ sections of tissue fixed as for Figure 1. A Penetrating into an islet $(\times 300)$, B Surrounding and enmeshing an islet $(\times 420)$ 


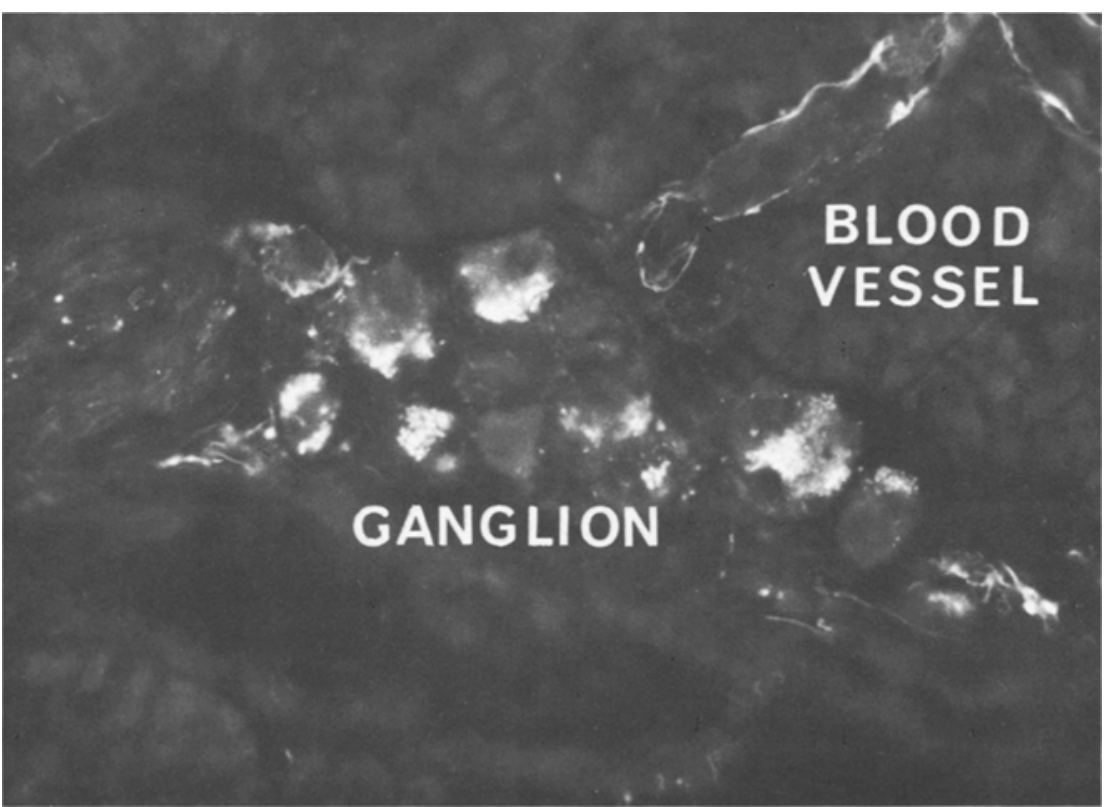

Fig. 3. Human pancreatic ganglion in $10 \mu$ section of tissue fixed and immunostained as for Fig 2. VIP immunoreactive and nonimmunoreactive ganglion cells and few VIP fibres can be seen within the ganglion. A blood vessel lies adjacent to the ganglion $(\times 430)$

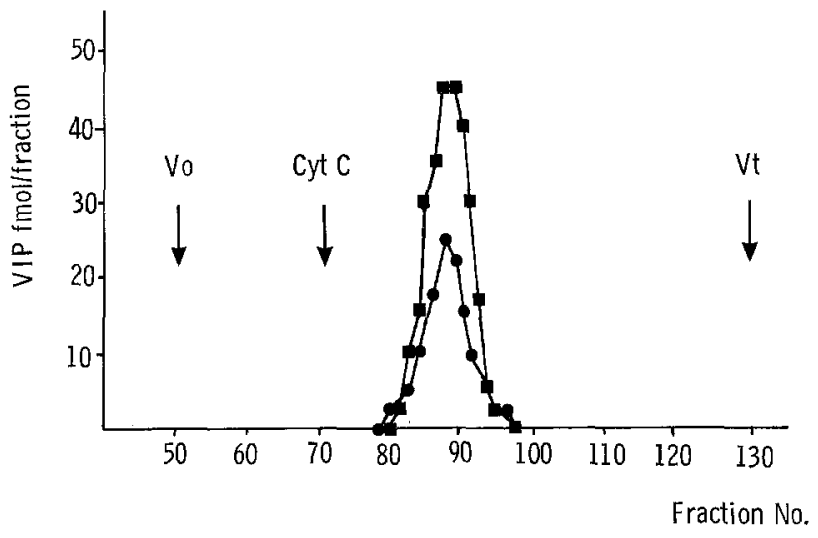

Fig. 4. Chromatography of VIP extracted from human pancreas $(\mathbf{I})$ and porcine VIP standard $(\bullet \bullet)$

Table 1. VIP content of human and rat pancreata. Numbers of samples shown in parentheses

\begin{tabular}{lll}
\hline Tissue & $\begin{array}{l}\text { VIP content (pmol/g) } \\
\text { wet weight } \pm \text { SEM }\end{array}$ \\
\hline $\begin{array}{l}\text { Human (18): } \\
\text { Pancreas (exocrine and } \\
\text { endocrine) - comprised of } \\
\text { groups shown below) }\end{array}$ & $41.6 \pm 10$ & $(18)$ \\
"Normal" pancreas surrounding & & \\
APUDoma & $56 \pm 11$ & $(7)$ \\
"Normal" pancreas surrounding & 38,34 & $(2)$ \\
carcinoma & 29,37 & $(2)$ \\
Normal surgical pancreas & $38 \pm 9$ & $(7)$ \\
Post mortem: Head & $49 \pm 6$ & $(7)$ \\
$\quad$ Body & $42 \pm 11$ & $(7)$ \\
$\quad$ Tail & $28 \pm 7$ & $(12)$ \\
Rat (22): & $374 \pm 30$ & $(10)$ \\
Whole pancreas & & \\
Isolated islets & &
\end{tabular}

\section{Radioimmunoassay (Table 1)}

Determination of VIP content by radioimmunoassay of tissue extracts revealed that (a) similar values were obtained for each specimen of human pancreas and for each region (head, body and tail) examined. Analysis of variance showed there was no significant difference between the values. (b) Human pancreas contained approximately $50 \%$ more VIP than rat pancreas. This difference approached significance $(\mathrm{p}<0.1)$.

\section{Chromatography}

In all cases (Fig. 4) a single major molecular form of VIP immunoreactivity was demonstrated in the chromatographs of human pancreatic extracts. This peak of VIP immunoreactivity eluted in an identical position to the standard natural porcine VIP used to calibrate the column, indicating considerable physico-chemical similarity between porcine intestinal and the human pancreatic VIP-like immunoreactivity.

\section{Discussion}

There appears to be a considerable quantity of VIP in the human and rat pancreas and this has been localised to fine, varicose nerve fibres. The VIP fibres were found to be in close contact with cells in both the exocrine and endocrine pancreas. As in other mammals, such as cat and pig [18] and dog [17], VIP immunoreactive ganglion cells were observed in the human pancreas. Thus, there may be an intrinsic sys- 
tem of peptidergic nerves in the pancreas, analogous to that known to exist in the gut [34].

The existence of VIP containing cells has been reported in dog, guinea-pig and human islets [35]. However, the immunostaining was further found to be abolished by the prior addition of glucagon to the VIP antiserum [36].

Under the conditions of the present study, using a C-terminally directed antiserum which did not cross react with glucagon, no VIP containing cells were detected.

Hickson [38] first showed that stimulation of the vagus causes bicarbonate secretion from the pancreas and that this effect is unaltered by atropine, suggesting the presence of a non-cholinergic neural mechanism. VIP is known to cause pancreatic alkaline juice flow $[14,16]$ and can also be released by stimulation of the vagus $[39,40]$. If VIP acts as a neurotransmitter, as has been widely suggested [41], then it is possible that the VIP fibres present in the acinar tissue are involved in the local control of exocrine pancreatic function. This postulate has been supported by the reported presence of specific receptors for VIP on the membranes of acinar cells [42].

Recently, evidence has accumulated for a role for VIP as an agent in the control of the endocrine, as well as exocrine, pancreas. Infusion of VIP into isolated dog pancreas releases somatostatin [12], insulin, glucagon and pancreatic polypeptide [15]. Similarly, perfusion of the isolated cat and pig pancreas with VIP has been shown to release both insulin and glucagon $[13,14]$. It is of considerable interest that the amounts of VIP required to release these two hormones, between 1 and $50 \mathrm{nmol} / 1$, are never attained in the circulation under normal physiological conditions. However it is possible that such concentrations could be reached locally by release of VIP directly on to the islets from peri-insular VIP fibres.

The unity between the structure and function of nerves and islets was first inferred by Van Campenhout when he referred to islets and adjacent autonomic nerve cell bodies as a "complex neuroinsulinaire" [43]. The original division of the autonomic nervous system into two components, cholinergic and adrenergic [44], has been challenged by the discovery of a considerable number and variety of peptidergic autonomic nerves. Recent immunocytochemical studies have localised VIP in some of the non-cholinergic, non-adrenergic autonomic fibres previously described as containing neurosecretory granules [45]. These nerves correspond to those in $\mathrm{p}$ (peptidergic)-type nerves, first described by Baumgarten et al. in 1970 [46]. Thus VIP nerves appear to be part of the autonomic nervous system and the finding of a high degree of VIP innervation of the islets further emphasises the close relationship between the autonomic nervous system and the endocrine pancreas.

The presence of VIP, a potent insulinotropic agent, in nerve fibres associated with the islets of Langerhans suggests, but provides no direct evidence for, a functional role. The investigation of the possible importance of the VIPergic innervation of the islet requires the development of new techniques to measure the local release of peptides from nerves or of specific VIPergic blocking agents to establish its significance particularly in the development of diabetes mellitus.

Acknowledgements. This work was carried out with generous support from the Medical Research Council, Janssen Pharmaceutical Limited and the Cancer Research Campaign.

We would like to thank the Department of Surgery, R.P.M.S., particularly Prof. R.B. Welbourn and Prof. L. H. Blumgart for specimens they provided.

We are grateful to Mrs. J. Bradburn for secretarial assistance.

\section{References}

1. Said S I, Mutt V (1972) Isolation from porcine intestinal wall of a vasoactive octacosapeptide related to secretin and glucagon. Eur J Biochem 28: 199-204

2. Bryant MG, Bloom S R, Polak J M, Albuquerque R H, Modlin I, Pearse A GE (1976) Possible dual role for vasoactive intestinal peptide as gastrointestinal hormone and neurotransmitter substance. Lancet I: 991-993

3. Larsson L-L, Fahrenkrug J, Schaffalitzky de Muckadell OB, Sundler F, Hakanson R, Rehfeld JF (1976) Localisation of vasoactive intestinal polypeptide (VIP) to central and peripheral neurons. Proc Natl Acad Sci 73: $3197-3200$

4. Said S I, Rosenberg R (1976) Vasoactive intestinal polypeptide. Abundant immunoreactivity in neural cell lines and normal nervous tissues. Science 192: 907--908

5. Polak J M, Bloom SR (1978) Peptidergic nerves of the gastrointestinal tract. Invest Cell Pathol 1: 301-326

6. Wharton J, Polak JM, Bryant MG, Van Noorden S, Bloom SR, Pearse AGE (1979) Vasoactive intestinal polypeptide (VIP)-like immunoreactivity in salivary glands. Life Sci 25: 273-280

7. Larsson L-I, Fahrenkrug J, Schaffalitzky de Muckadell OB (1977) Occurrence of nerves containing vasoactive intestinal polypeptide immunoreactivity in the male genital tract. Life Sci 21: 503-508

8. Larsson L-I, Fahrenkrug J, Schaffalitzky de Muckadell OB (1977) Vasoactive intestinal polypeptide occurs in nerves of the female genitourinary tract. Science 197: 1374-1375

9. Bishop A E, Polak JM, Bloom S R (1979) Vasoactive intestinal polypeptide innervation of the genital tract of women. $\mathbf{J}$ Endocrinol 80: 33-34

10. Alm P, Alumets J, Hakanson R, Sundler F (1977) Peptidergic (vasoactive intestinal peptide) nerves in the genitourinary tract. Neuroscience 2: 751-754

11. Makhlouf GM, Said S I (1975) The effect of vasoactive intestinal polypeptide (VIP) on digestive and hormonal function. In: Thompson JC (ed) Gastrointestinal hormones: A Symposium. Univ. Texas Press, Austin London, p 599-610

12. Ipp E, Dobbs RE, Unger RH (1978) Vasoactive intestinal peptide stimulates pancreatic somatostatin release. FEBS Lett 90: $76-78$ 
13. Schebalin M, Said SI, Makhlouf GM (1977) Stimulation of insulin and glucagon secretion by vasoactive intestinal peptide. Am J Physiol 232: 197-200

14. Lindkaer Jensen S, Fahrenkrug J, Holst J J, Vagn Nielsen O, Schaffalitzky de Muckadell OB (1978) Secretory effects of VIP on isolated perfused porcine pancreas. Am J Physiol 235: 387-391

15. Adrian TE, Bloom SR, Hermansen K, Iversen J (1978) Pancreatic polypeptide, glucagon and insulin secretion from the isolated perfused canine pancreas. Diabetologia 14: 413-417

16. Holst J J, Schaffalitzky de Muckadell OB, Fahrenkrug J (1979) Nervous control of pancreatic exocrine secretion in pigs. Acta Physiol Scand 105: 33-51

17. Larsson LI, Fahrenkrug J, Holst J J, Schaffalitzky de Muckadell OB (1978) Innervation of the pancreas by vasoactive intestinal polypeptide (VIP) immunoreactive nerves. Life Sci 22: 773-780

18. Sundler F, Alumets J, Hakanson R, Fahrenkrug J, Schaffalitzky de Muckadell OB (1978) Peptidergic (VIP) nerves in the pancreas. Histochemistry 55: 173-176

19. Pearse A GE, Welbourn RB (1973) The APUDomas. Br J Hosp Med 10: 617-624

20. Howell SL, Taylor KW (1968) Potassium ions and the secretion of insulin by islets of Langerhans incubated in vitro. Biochem J 108: 17-24

21. Gay JO, Gay MK (1936) Maintenance of the human normal cell in continuous culture. Preliminary report: Cultivation of mesoblastic tumours and normal tissue and notes on methods of cultivation. Am J Cancer 27: 45-76

22. Pearse AGE, Polak JM (1975) Bifunctional reagents as vapour and liquid phase fixatives for immunocytochemistry. Histochem J 7: 179-186

23. Bishop AE, Polak J M, Bloom SR, Pearse AGE (1978) A new universal technique for the immunocytochemical localisation of peptidergic innervation. J Endocrinol 77: 25-26

24. Sternberger LA (1974) The unlabelled antibody enzyme method. In: Immunocytochemistry. Prentice Hall Inc., Englewood Cliffs, p-129-171

25. Graham RC, Karnovsky MJ (1966) The early stages of absorption of injected horseradish peroxidase in the proximal tubules of mouse kidney: Ultrastructural cytochemistry by a new technique. J Histochem Cytochem 14: 291-302

26. Mitchell SJ, Bloom SR (1978) Measurement of fasting and postprandial plasma VIP in man. Gut 19: 1043-1048

27. Wharton J, Polak JM, Bloom SR, Ghatei MA, Solcia E, Brown MR, Pearse AGE (1978) Bombesin-like immunoreactivity in the lung. Nature 273: 769-770

28. Buchan AMJ, Polak JM, Solcia E, Pearse AGE (1979) Localisation of intestinal gastrin in a distinct endocrine cell type. Nature 277: 138-140

29. Polak JM, Pearse AGE, Szelke M, Bloom SR, Hudson D, Facer P, Buchan AMJ, Bryant MG, Christophodes N, MacIntyre I (1977) Specific immunostaining of CCK cells by the use of synthetic fragment antisera. Experientia 33: 762-763

30. Polak JM, Sullivan SN, Bloom SR, Buchan AMJ, Facer P, Brown MR, Pearse AGE (1977b) Specific localisation of neurotensin to the $\mathrm{N}$ cell in human intestine by radioimmunoassay and immunocytochemistry. Nature 270: 183-184

31. Polak J M, Pearse A GE, Grimelius L, Bloom S R, Arimura A (1975) Growth-hormone releasing inhibiting hormone (GH$\mathrm{RIH}$ ) in gastrointestinal and pancreatic D cells. Lancet I: $1220-1222$

32. Wharton J, Polak JM, Bloom SR, Will JA, Brown MR, Pearse A GE (1979) Substance P-like immunoreactive nerves in mammalian lung. Invest Cell Pathol 2: 3-10
33. Polak JM, Sullivan SN, Bloom SR, Facer P, Pearse AGE (1977) Enkephalin-like immunoreactivity in the human gastrointestinal tract. Lancet I: 972-974

34. Jessen KR, Polak JM, Van Noorden S, Bryant MG, Bloom SR, Burnstock G (1979) A new approach to the demonstration of the enteric plexus origin of peptide-containing nerves by immunocytochemistry and radioimmunoassay. Gastroenterology 76: 1161

35. Buffa R, Capella C, Solcia E, Frigerio B, Said S (1977) Vasoactive intestinal polypeptide (VIP) cells in the pancreas and gastrointestinal mucosa. An immunohistochemical and ultrastructural study. Histochemistry 50: 217-227

36. Buffa R, Capella C, Fontana P, Usellini L, Solcia E (1978) Types of endocrine cells in the human colon and rectum. Cell Tissue Res 192: 227-240

37. Larsson L-I, Polak JM, Buffa R, Sundler F, Solcia E (1979) On the immunocytochemical localisation of the vasoactive intestinal polypeptide. J Histochem Cytochem 27: 936-938

38. Hickson JCD (1970) The secretory and vascular response to nerves and hormonal stimulation in the pancreas of the pig. $J$ Physiol (Lond) 206: 299-322

39. Schaffalitzky de Muckadell OB, Fahrenkrug J, Holst JJ (1977) Release of VIP by electric stimulation of the vagal nerves. Gastroenterology 72: 373-375

40. Fahrenkrug J, Galbo H, Holst J J, Schaffalitzky de Muckadell OB (1978) Influence of the autonomic nervous system on the release of vasoactive intestinal polypeptide from the porcine gastrointestinal tract. J Physiol (Lond) 280: 405-422

41. Fahrenkrug J, Haglund U, Jodal M, Lundgren O, Olbe L, Schaffalitzky de Muckadell OB (1978) Possible physiological implications of nervously released vasoactive intestinal polypeptide (VIP) in the gastrointestinal tract. Scand J Gastroenterol 13 [Suppl 49]: 59

42. Gardner J D, Christophe J, Robberecht P (1977) Membrane receptors for vasoactive intestinal polypeptide and secretin in pancreatic acinar cells. In: Bonfils S (ed) Hormonal receptors in digestive tract physiology. North-Holland, Amsterdam, $p$ 227-235

43. Campenhout E van (1927) Contribution a l'étude de l'histogénèse du pancreas chez quelques mammiféres. Les complexes sympathetico-insulinaires. Arch Biol (Liège) 37: 121-171

44. Langley JN (1898) The sympathetic and other related systems of nerves. Schaffer EA (ed) Textbook of physiology, 1. Pentland, Edinburgh, p 475-530

45. Larsson L-I (1977) Localisation of a new neural peptide (VIP) by electron microscopy and immunocytochemistry. Histochemistry 54: 173-176

46. Baumgarten HG, Holstein AF, Owman C (1970) Auerbach's plexus of mammals and man - electron microscopical identification of three different types of neuronal processes in myenteric ganglia of the large intestine from rhesus monkeys, guinea-pigs and man. Z Zellforsch 106: 376-397

Received: May 4, 1979 , and in revised form: October 6, 1979

Dr. J. M. Polak

Department of Histochemistry

Hammersmith Hospital

Ducane Road

London W12 OHS

England 